\title{
Common carotid artery injury caused by a camel bite: case report and systematic review of the literature
}

\author{
Fikri M Abu-Zidan, M.D., ${ }^{1}$ Saleh Abdel-Kader, M.D., ${ }^{2}$ Radwan El Husseini, M.D. ${ }^{2}$ \\ ${ }^{1}$ Trauma Group, Faculty of Medicine and Health Sciences, UAE University, Al-ain, UAE \\ ${ }^{2}$ Department of Surgery, Vascular Surgery Unit, Al-ain Hospital, Al-ain, UAE
}

\begin{abstract}
A 25-year-old man was bitten in the neck by an aggressive camel, causing three small puncture wounds. The left carotid pulse of the patient was weakly palpated. Angiography showed irregular dissection of the distal part of the left common carotid artery. Neck exploration confirmed the findings. An interposition autogenous saphenous vein graft was performed successfully. The patient was discharged home in good condition. We have systematically reviewed the literature on this topic, and only four other similar cases were reported previously. Although camel bite wounds are small, they may penetrate deeply, causing serious injuries to the neck structures including the major vessels. Care should be taken when approaching male camels during the rutting season.
\end{abstract}

Key words: Camel; carotid artery; injury; neck bite; trauma.

\section{INTRODUCTION}

Animal bites are an underestimated public health problem worldwide. In Australia, nearly $2 \%$ of the population is bitten by animals every year; more than $80 \%$ by dogs. ${ }^{[1]}$ Biting of the neck, which is crowded with vital structures, may lead to major vascular and neurological injuries. We have previously reported the devastating injuries caused by camel bites to the neck. ${ }^{[2]}$ Major vascular injuries of the neck caused by camel bites are extremely rare. Herein, we report a patient who sustained a common carotid artery (CCA) injury caused by a camel bite, and we systematically review the literature on this topic.

\section{CASE REPORT}

A 23-year-old Pakistani camel caregiver presented to the Emergency Department of Al-Ain Hospital two hours after being bitten in the neck by an aggressive camel. On examination, the patient was fully conscious and talking. His blood

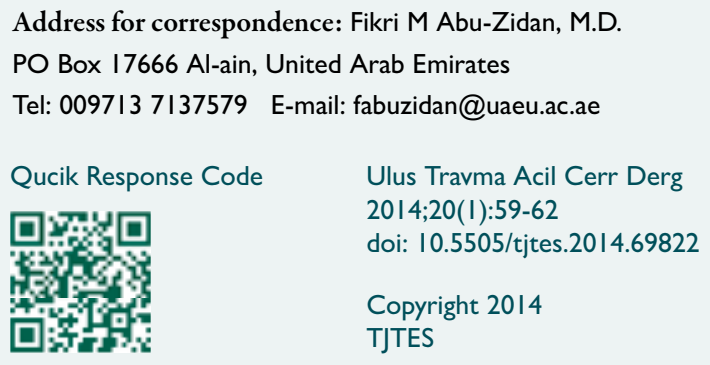

pressure was $140 / 80 \mathrm{mmHg}$, pulse rate $78 \mathrm{bpm}$, and body temperature $37.8{ }^{\circ} \mathrm{C}$. Three small puncture wounds to the left side of the neck were seen. Surgical emphysema of the neck and upper chest were felt on palpation. The left carotid artery pulse was weak. Carotid bruit could not be heard. The patient could not abduct his left arm. He received tetanus toxoid intramuscularly and was admitted to the hospital.

Computerized tomography (CT) scan of the neck with intravenous and oral contrast showed non-visualization of the left CCA and surgical emphysema of the neck. There was no leakage of the oral contrast. CT angiography showed that the left CCA was non-contrasted from its origin up to the bifurcation (Figure la). Contrast magnetic resonance (MR) angiogram showed intimal tear of the left CCA $2-3 \mathrm{~cm}$ below the bifurcation (Figure Ib). Carotid angiogram confirmed the findings. The left CCA was partially patent. Fibro-optic laryngoscopy was normal.

Exploration of the neck showed a thrombus and dissection in the distal part of the left CCA $2 \mathrm{~cm}$ below the bifurcation. The stump pressure of the left internal carotid artery was 70/40 $\mathrm{mmHg}$. The artery was opened at the site of the hematoma, and a circumferential intimal tear and overlying thrombus were found (Figure Ic). The section of the left CCA containing the intimal tear was excised, and an interposition autogenous saphenous vein graft was performed. A suction drain was inserted, and the wound was primarily closed in layers. The patient

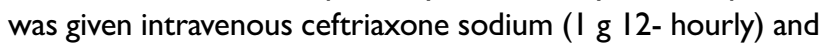
metronidazole (500 mg 8-hourly) for one week. 

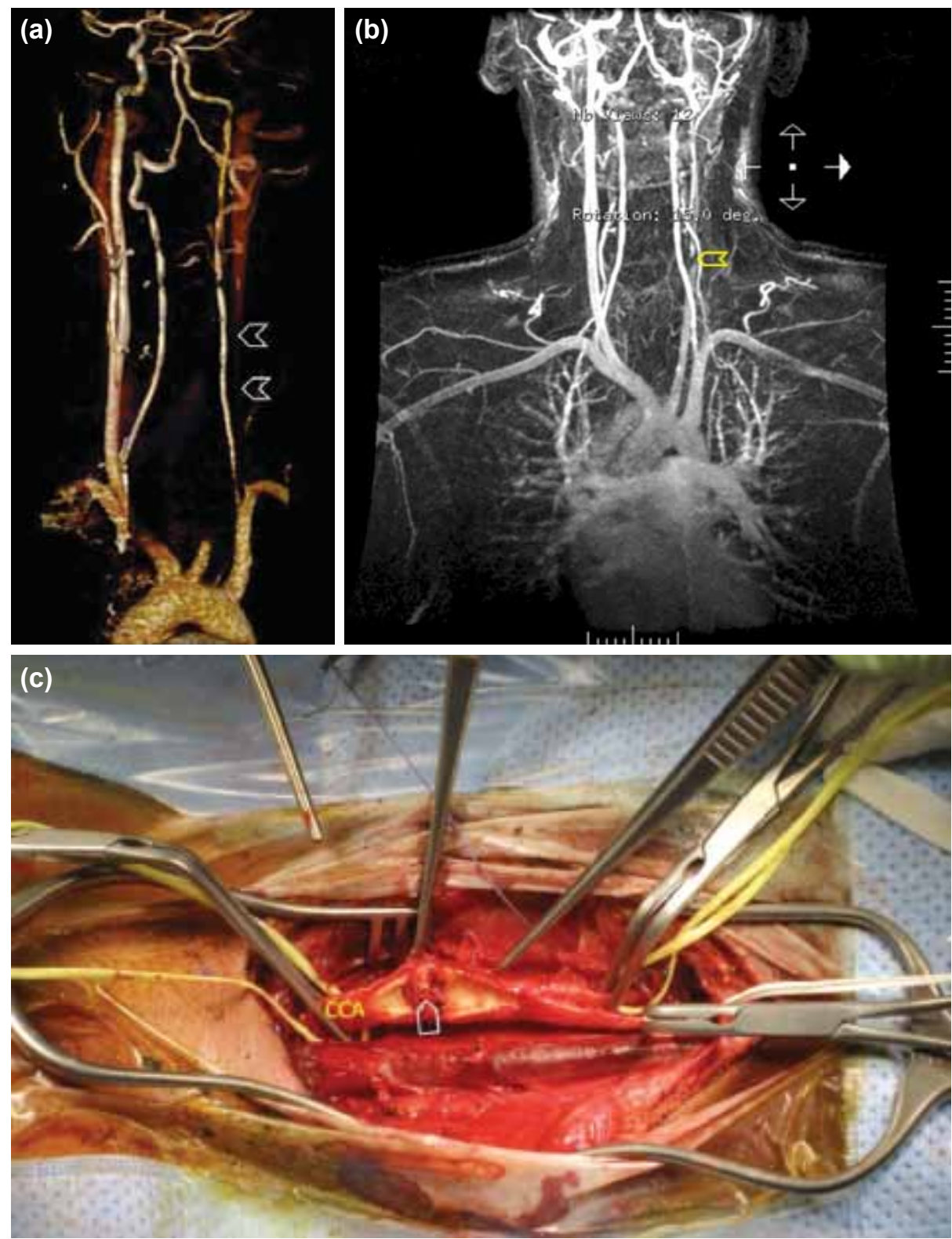

Figure 1. (a) CT angiography showing that the left CCA was non-contrasted from its origin up to the carotid bifurcation (arrow heads) and a good back flow in the circle of Willis. (b) MR angiogram with contrast showing intimal tear in the left CCA 2-3 cm below the bifurcation (arrow head). (c) Arteriotomy showing dissection of the distal part of the left CCA, about $2 \mathrm{~cm}$ below the bifurcation.

Follow-up Doppler ultrasound study showed good flow in the left common, internal, and external carotid arteries. Nerve conduction velocity and electromyography showed neurapraxia of the left brachial plexus including the left axillary, musculocutaneous and supra-scapular nerves. The patient received physiotherapy for the brachial plexus injury. The patient had a smooth postoperative recovery, and was scheduled to be discharged on the 10th postoperative day. Nevertheless, he was kept in the hospital for social reasons and was discharged home on day 20 on aspirin tablets, 100 mg daily. A follow-up at one month showed improvement in the left arm abduction.

\section{DISCUSSION}

Although the principles of surgical management of carotid artery injuries are well-known, camel bites as a cause of these injuries are extremely rare and unique. A search of Medline revealed only five cases of major vascular injuries of the neck caused by camel bites, including the present case (Table 1). ${ }^{[2-5]}$ Three of these were reported from our hospital. This indicates that these injuries are under-reported because the majority occur in developing countries with a lack of training in research and medical writing. The estimated incidence of camel bite injuries requiring hospitalization in our city is $\mathbf{I . 5}$ per 100,000 inhabitants per year. ${ }^{[6]}$ 
Table I. Summary of reported cases in the literature of major vascular injuries of the neck caused by camel bites

\begin{tabular}{|c|c|c|c|c|c|c|c|c|}
\hline Author & $\begin{array}{l}\text { Age } \\
\text { (yrs) }\end{array}$ & Sex & $\begin{array}{l}\text { Mechanism of } \\
\text { injury }\end{array}$ & $\begin{array}{l}\text { Clinical } \\
\text { presentation }\end{array}$ & Wound & Injuries & Management & Outcome \\
\hline $\begin{array}{l}\text { Janjua } K J^{[3]} \\
(1993)\end{array}$ & 52 & Male & $\begin{array}{l}\text { Bitten by a camel, } \\
\text { lifted up and } \\
\text { thrown aside }\end{array}$ & $\begin{array}{l}\text { Swollen left } \\
\text { shoulder, absent } \\
\text { left radial pulse }\end{array}$ & $\begin{array}{l}\text { Bite mark } \\
\text { on the left } \\
\text { shoulder } \\
\text { without } \\
\text { penetration }\end{array}$ & $\begin{array}{l}\text { Left subclavian } \\
\text { artery occlusion, } \\
\text { fractured } \\
\text { clavicle, } \\
\text { fractured ribs } \\
\text { (I-3) left side }\end{array}$ & $\begin{array}{l}\text { Gortex graft } \\
\text { bridging a } 5 \mathrm{~cm} \\
\text { loss of the } \\
\text { subclavian artery }\end{array}$ & $\begin{array}{l}\text { Complete } \\
\text { recovery }\end{array}$ \\
\hline $\begin{array}{l}\text { Nawaz et al. }{ }^{[4]} \\
(2005)\end{array}$ & 11 & Male & Camel bite & Neck wound & $\begin{array}{l}\text { Four } \\
\text { puncture } \\
\text { wounds on } \\
\text { left side of } \\
\text { the neck, ear } \\
\text { and cheek }\end{array}$ & $\begin{array}{l}\text { Intimal tear of } \\
\text { the left internal } \\
\text { carotid artery } \\
\text { without } \\
\text { occlusion, } \\
\text { fractured } \\
\text { mandible }\end{array}$ & $\begin{array}{l}\text { Interposition } \\
\text { venous graft } \\
\text { bridging a } 2 \mathrm{~cm} \\
\text { defect ORIF } \\
\text { of mandible }\end{array}$ & $\begin{array}{l}\text { Complete } \\
\text { recovery }\end{array}$ \\
\hline $\begin{array}{l}\text { Shehu et al. } .^{[5]} \\
(2007)\end{array}$ & 30 & Male & Camel bite & $\begin{array}{l}\text { Loss of } \\
\text { consciousness, } \\
\text { right hemiparesis }\end{array}$ & $\begin{array}{l}\text { Four } \\
\text { puncture } \\
\text { wounds on } \\
\text { the left side } \\
\text { of the neck }\end{array}$ & $\begin{array}{l}\text { Left carotid } \\
\text { artery } \\
\text { occlusion, left } \\
\text { brain infarction }\end{array}$ & Conservative & $\begin{array}{l}\text { Right } \\
\text { hemiparesis }\end{array}$ \\
\hline $\begin{array}{l}\text { Abu-Zidan et al. }{ }^{[2]} \\
(2007)\end{array}$ & 45 & Male & $\begin{array}{l}\text { Bitten by a camel, } \\
\text { lifted up and } \\
\text { thrown to the } \\
\text { ground }\end{array}$ & $\begin{array}{l}\text { Unconscious, } \\
\text { dyspnea, shock, } \\
\text { right hemiparesis }\end{array}$ & $\begin{array}{l}\text { Lacerated } \\
\text { wounds of } \\
<2 \mathrm{~cm} \text { on } \\
\text { the left side } \\
\text { of the neck }\end{array}$ & $\begin{array}{l}\text { Left carotid } \\
\text { artery injury } \\
\text { without } \\
\text { occlusion, } \\
\text { massive left } \\
\text { brain infarction, } \\
\text { fractured cervical } \\
\text { spine, massive } \\
\text { left hemothorax, } \\
\text { fractured clavicle } \\
\text { and ribs }(1-2) \\
\text { on left side }\end{array}$ & Conservative & Exitus \\
\hline Present case & 23 & Male & Camel bite & $\begin{array}{l}\text { Neck wound, } \\
\text { inability to abduct } \\
\text { the left arm }\end{array}$ & $\begin{array}{l}\text { Puncture } \\
\text { wounds on } \\
\text { left side of } \\
\text { the neck }\end{array}$ & $\begin{array}{l}\text { Intimal tear of } \\
\text { the left common } \\
\text { carotid artery, } \\
\text { left brachial } \\
\text { plexus injury }\end{array}$ & $\begin{array}{l}\text { Interposition } \\
\text { venous graft } \\
\text { bridging a } 3 \mathrm{~cm} \\
\text { defect }\end{array}$ & $\begin{array}{l}\text { Mild paresis } \\
\text { of left } \\
\text { brachial } \\
\text { plexus }\end{array}$ \\
\hline
\end{tabular}

ORIF: Open reduction/internal fixation.

The mechanism of camel bite injury is complex, including penetrating and crushing injuries by the camel teeth, and blunt injuries when patients are lifted and thrown to the ground. ${ }^{[2]}$ More than $20 \%$ of the patients who had camel bites were lifted by the camel's teeth and thrown aside. ${ }^{[6]}$ Two of the five patients in Table I were lifted and thrown to the ground after being bitten. The increased complexity of the mechanism of injury will increase its severity. ${ }^{[7]}$

All patients in Table I were males, with a median age (range) of 30 (I I-54) years. Similarly, in a prospective study of 212 camel-related injuries from the United Arab Emirates, all the patients were male. ${ }^{[8]}$

The presented patient was injured in January. More than $70 \%$ of camel bites occur during the rutting season, which is between November and March, during which the male camels become irritable and difficult to handle. ${ }^{[6,9]}$ An air-filled pink diverticulum called the "dulla", reaching up to $25 \mathrm{~cm}$ in length, protrudes from the mouth of a sexually active camel. ${ }^{[6]}$

The camel bites thin areas of the body, including the upper limbs and neck. About $8 \%$ of camel bites involve the neck. ${ }^{[8]}$ Despite the small size of the puncture wounds of these bites, they penetrate deeply, causing serious injuries to deeper structures, as shown in Table I. Of these five patients, one patient died, one had right-sided hemiparesis, and another had left brachial plexus paresis. Three patients underwent successful interposition grafting of major vascular injuries of the neck. Interestingly, all wounds were on the left side of the neck, which may be related to the behavior of the camel when it attacks the neck of humans.

Selective surgery for penetrating injury of the neck is accepted in civilian trauma centers with proper diagnostic facilities. $^{[10,11]}$ Hard signs serving as reliable indicators for carotid 
artery injury include an expanding or pulsatile hematoma, absence of pulse, presence of bruit, and an active external bleeding. Patients who are hemodynamically stable can be observed clinically and evaluated using radiological investigations. ${ }^{\left[{ }^{11}\right]}$ The carotid pulse in our patient was weak and not completely absent. Since he was hemodynamically stable, we decided to do a workup before surgery. The best option for surgical repair of the carotid artery injury, if there is any possibility of tension, is an autogenous saphenous vein graft. ${ }^{[1]}$

We treated our patient with tetanus toxoid and antibiotics, similar to Saxena et al., ${ }^{[12]}$ who reported the management of the largest series of camel bites in the literature and did not report any case of rabies in their study. Nevertheless, we think that anti-rabies prophylaxis for camel bites should be given in the future because of the risk of rabies. ${ }^{[13]}$

In conclusion, although camel bite wounds are small, they may penetrate deeply, causing serious injuries to neck structures, including the major vessels. Care should be taken when approaching male camels during the rutting season. Rutting camels are recognized by the pink "dulla" protruding from their mouths.

Conflict of interest: None declared.

\section{REFERENCES}

1. MacBean CE, Taylor DM, Ashby K. Animal and human bite injuries in
Victoria, 1998-2004. Med J Aust 2007;186:38-40.

2. Abu-Zidan FM, Ramdan K, Czechowski J. A camel bite breaking the neck and causing brain infarction. J Trauma 2007;63:1423. CrossRef

3. Janjua KJ. Camel bite injury: an unusual report of left shoulder mutilation with major vascular and bony injuries. Injury 1993;24:686-8. CrossRef

4. Nawaz A, Matta H, Hamchou M, Jacobsz A, Al Salem AH. Camel-related injuries in the pediatric age group. J Pediatr Surg 2005;40:1248-51.

5. Shehu BB, Nasiru JI, Mahmud MR, Laseini A, Saidu SA. Carotid occlusion and cerebral infarction from camel bite: case report. East Afr Med J 2007;84:550-2.

6. Abu-Zidan FM, Eid HO, Hefny AF, Bashir MO, Branicki F. Camel bite injuries in United Arab Emirates: a 6 year prospective study. Injury 2012;43:1617-20. CrossRef

7. Abu-Zidan FM, Rao S. Factors affecting the severity of horse-related injuries. Injury 2003;34:897-900. CrossRef

8. Abu-Zidan FM, Hefny AF, Eid HO, Bashir MO, Branicki FJ. Camel-related injuries: prospective study of 212 patients. World J Surg 2012;36:2384-9. CrossRef

9. Food and agriculture organization of the United Nations. A manual for the primary animal health care worker: chapter 7: camels, llamas and alpacas. http://www.fao.org/docrep/T0690E/t0690e09.htm\#chapter 7. Accessed 1st August 2012.

10. Ordog GJ, Albin D, Wasserberger J, Schlater TL, Balasubramaniam S. 110 bullet wounds to the neck. J Trauma 1985;25:238-46. CrossRef

11. Asensio JA, Vu T, Mazzini FN, Herrerias F, Pust GD, Sciarretta J, et al. Penetrating carotid artery: uncommon complex and lethal injuries. Eur J Trauma Emerg Surg 2011;37:429-37. CrossRef

12. Saxena PS, Sharma SM, Singh M, Saxena M. Camel bite injuries.J Indian Med Assoc 1982;79:65-8.

13. Bloch N, Diallo I. A probable outbreak of rabies in a group of camels in Niger. Vet Microbiol 1995;46:281-3. CrossRef

\title{
OLGU SUNUMU - ÖZET
}

\section{Deve ısırı̆̆ının neden olduğu ana karotis arter yaralanması: \\ Olgu sunumu ve literatürün sistematik biçimde gözden geçirilmesi \\ Dr. Fikri M Abu-Zidan, ${ }^{1}$ Dr. Saleh Abdel-Kader, ${ }^{2}$ Dr. Radwan El Husseini ${ }^{2}$}

\author{
${ }^{1}$ Birleşik Arap Emirlikleri Üniversitesi, Tıp ve Sağlık Bilimleri Fakültesi, Travma Grubu, Al-ain, BAE \\ ${ }^{2} \mathrm{Al}-$-ain Hastanesi, Cerrahi Bölümü, Vasküler Cerrahi Ünitesi, Al-ain, BAE
}

Yirmi beş yaşında bir erkek saldırgan bir deve tarafından boynundan ısırıımış ve boynunda üç küçük delici yara oluşmuştur. Sol karotis nabzı zayıf hissediliyordu. Anjiyografi sol ana karotis arterin distal segmentinde düzensiz kesiler olduğunu gösterdi. Boynun eksplorasyonu bu bulguları doğruladı. Otojen safen ven greft interpozisyonu başarıyla uygulandı. Hasta evine iyi durumda gönderildi. Bu konuya ilişkin literatürü sistematik biçimde gözden geçirdik ve yalnızca dört adet benzer olgu raporuna rastladık. Deve ısırı̆ı yaraları küçük boyutlarda olmalarına rağmen derine penetre olabilerek ana damarlar dahil boyun oluşumlarında ciddi yaralanmalara neden olabilirler. Azgınlık dönemlerinde erkek develere yaklaşırken dikkatli olunmalıdır. Anahtar sözcükler: Boyun ısırı̆ı; deve; karotis arter; travma; yaralanma. 